\title{
METHODS
}

UDC 620.3:615.2/.3:57.016.7

doi: https://doi.org/10.15407/ubj93.01.104

\section{APPLICATION OF FLUORESCEIN COPOLYMER TO IMPROVE THE EFFICIENCY OF COUNTER-IMMUNOELECTROPHORESIS FOR DIAGNOSTICS OF ANIMAL INFECTIOUS DISEASES}

\author{
D. D. OSTAPIV $V^{1}$, N. V. KUZ'MINA', M. R. KOZAK ${ }^{1}$, \\ SHAN HU⿱2 , V. V. VLIZLO ${ }^{3 凶, ~ I . ~ Y a . ~ K O T S I U M B A S ~}$, S. M. VARVARENKO ${ }^{4}$, \\ V. Ya. SAMARYK ${ }^{4}$, N. G. NOSOVA , M. V. YAKOVIV ${ }^{4}$ \\ ${ }^{1}$ Institute of Animal Biology, NAAS of Ukraine, Lviv, Ukraine; \\ ${ }^{2}$ Qingdao Agricultural University, Qingdao, China; \\ ${ }^{3}$ State Scientific-Research Control Institute of Veterinary Medicinal \\ Products and Feed Additives, Lviv, Ukraine; \\ ${ }^{4}$ Lviv Polytechnic National University, Lviv, Ukraine; \\ 凶e-mail: vasyl.vlizlo@scivp.lviv.ua
}

Received: 12 May 2020; Accepted: 17 December 2020

The counter-immunoelectrophoresis (CIE) is a highly specific, simple and rapid method, which does not require expensive equipment, input materials and long-term staff training as compared with other express methods of viral infections diagnostic. Despite the CIE high informativeness, the results in practice can be doubtful at times. Therefore, the purpose of the study was to improve CIE method by strengthening the antigen-antibody interaction with the use of synthesized amphiphilic fluorescein-containing copolymer. It was demonstrated that the use of the fluorescein copolymer -antigen complex enhanced the interaction with serum/ plasma antibodies of rabbits immunized against hemorrhagic disease and increased protein content in the area of precipitation. This effect was more pronounced when more hydrophobic copolymer containing 5.87\% fluorescein was introduced into the complex with antigen. The ability of the amphiphilic fluorescein copolymer to enhance the antigen-antibody interaction and the ability to visualize the fluorescent precipitation zone may increase CIE effectiveness for express diagnostic of infectious diseases.

Ke ywords: counter-immunoelectrophoresis, amphiphilic fluorescein copolymer, rapid diagnostics, rabbit hemorrhagic disease.

$\mathrm{T}$ he concentration of a large number of animals in a confined space due to industrial technologies for animal housing causes problems of rapid development and spread of various infectious diseases of both bacterial and viral origin. In case of infectious diseases it is important to conduct urgent rapid diagnostics with the aim of establishing the pathogen, and immediate development of effective measures of infection elimination and prevention.

The counter-immunoelectrophoresis (CIE), immunofluorescence (IF), solid-phase hemadsorption
(SPHA) and others tests are used for rapid diagnostics of viral infections. Among these methods, the CIE does not require expensive equipment and longterm staff training; it is simple and rapid to perform $[1,2]$. CIE is based on the precipitation reaction for the detection of specific antibodies against the pathogen. It is known that precipitating antibodies, most of which belong to class $\mathrm{G}$ immunoglobulins (IgG), under certain conditions of electrophoresis in an electric field move to the cathode. The antigen has a positive charge and moves to the anode. Since the

(C) 2021 Ostapiv D. D. et al. This is an open-access article distributed under the terms of the Creative Commons Attribution License, which permits unrestricted use, distribution, and reproduction in any medium, provided the original author and source are credited. 
antigen and antibody move in opposite directions, due to the electric field, their migration occurs towards each other. Visible precipitates appear after 30-60 minutes from the beginning of CIE [3].

This assay is used for the diagnostics of infectious diseases in veterinary and human medicine [4-7]. In particular, in the diagnosis of Aleutian mink disease of viral origin, CIE is characterized by high specificity and allows the detection of the disease on 6-15 days after infection. After experimental infection of animals, the disease is detected on 6-7 days when CIE is used $[1,8]$. For suckling puppies, the reaction becomes positive within the first hour after suckling the sick females' milk, which has maternal antibodies. The diagnostic efficiency of Aleutian mink disease is $98-100 \%$. CIE assay is also highly informative for the diagnosis of coronavirus infection for cattle [9].

Sometimes, the results of CIE can be doubtful. In such cases, for antigen-antibody precipitate detection, the agar gel is immersed in $12.5 \% \mathrm{NaCl}$ solution for 7-10 min or stained (1\% Amido black 10-B or $1 \%$ tannin solution), and then immunoelectrophoregrams are washed. If the result is questionable, the study should be repeated. These additional procedures delay the diagnosis of the disease, which is undesirable because of the rapid development of viral infection.

Our previous studies $[10,11]$ showed that one of the ways to increase the antigen-antibody interaction during immunoelectrophoresis is the appliance of an amphiphilic fluorescein-containing copolymer. This copolymer is able to enhance protein molecule binding and facilitate visualization due to visible fluorescence. During the study of an interaction between the obtained polymers and albumin, their ability to bind up to $70 \%$ of blood proteins was established [12-14].

The aim of the research was to improve the specificity of the CIE reaction due to the synthesized amphiphilic fluorescein-containing copolymer by enhancing the antigen + antibody interaction, which can be used for rapid diagnosis of infectious diseases.

\section{Materials and Methods}

Fluorescein copolymers obtained by Steglich reaction were used for the studies [13].

Antigens. For immunization of rabbits were used the antigens of two strains: BG- $04 \geq 640$ hemagglutinating units and GBK- 2 of $\geq 640$ hemag- glutinating units. These strains are the basis of the inactivated vaccine against hemorrhagic disease of rabbits (Lapimun GEM-2). The pathogen of rabbit hemorrhagic disease is a virus that contains RNA and possess a very high virulence. The vaccine administration protects rabbits against hemorrhagic disease for 12 months, and protective antibodies are produced on 4-14 days after vaccination [15].

Animals and immunization procedure. All animals were maintained in a specific pathogen-free animal facility with water and commercial food provided ad libitum. The protocol for animal experiments was approved by the Ethical Committee of the Institute of Animal Biology of NAAS of Ukraine and the experiments were carried out in accordance with the European Convention for the Protection of Vertebrate Animals (Strasbourg, 1986). 1-month-old rabbits of the Termonic White breed $(n=9)$ were selected for the experiments. To obtain specific antibodies, the rabbits were immunized with the Lapimun GEM-2 vaccine, which was administered subcutaneously under shoulder-blade. Dosing was based on manufacturer's recommendation - $1.0 \mathrm{ml}$ per head. The experiments were conducted in two stages: for 21 days $(n=6)$ and, repeatedly for 28 days $(n=3)$. Before vaccination (0 days) and after immunization on 14, 21 and 28 days a blood samples were taken into heparin tubes from the marginal auricual vein of rabbits.

Preparation of agar gel. To carry out immunoelectrophoresis, a $1 \%$ agar solution was prepared on 1:1 diluted tris-glycine buffer $(\mathrm{pH} 8.8)$. The heated agar solution (temperature $\sim 60^{\circ} \mathrm{C}$ ) was poured by $20-25 \mathrm{ml}$ onto glass plates $(6 \times 11 \mathrm{~cm})$ placed on a table to prepare gel samples for horizontal electrophoresis. After the agar was solidified (after 15-20 min), two parallel rows of $10-15 \mu$ holes were produced by the punch, with a distance of $1 \mathrm{~cm}$ between the rows.

Sample processing. Antigen samples were prepared as follows: $5 \mu \mathrm{l}$ of $1.0 \%$ solutions of fluorescein copolymer in two modifications (MF-37 and MF-47) were added to $1 \mathrm{ml}$ of vaccine against hemorrhagic rabbit disease (Lapimun GEM-2). The samples of amphiphilic fluorescein-containing copolymer differed in the fluorescein content.

$10 \mu \mathrm{l}$ of antigen (Lapimun GEM-2 vaccine) were introduced into the holes situated closer to the cathode: control one (without adding fluorescein copolymer; sample No. 1) and two experimental ones with the addition of MF-37 (sample No. 2) and MF- 
47 (sample No. 3). Each blood sample was divided into 3 parts and $10 \mu 1$ of blood plasma were introduced into the holes closer to the anode.

Counter-immunoelectrophoresis. CIE was performed in a BIO-RAD chamber (200 V; $10 \mathrm{~mA}$ ) for 25-30 min. The movement of fluoricein and the appearance of precipitation zones were visually controlled. After immunoelectrophoresis, the agar gel plates were covered with a transparent film and the results of the studies were recorded by direct scanning of the immunoelectrophoregrams (HP Scanjet G2410, United Kingdom). Protein content in the precipitation zones was determined using TotalLab TL120 software.

Statistical analysis. Statistical calculations of results $(M \pm m)$ were performed using the Microsoft Excel 2007. The probability of differences was determined by the Student's $t$-test with $P<0.05$ accepted as statistically significant.

\section{Results and Discussion}

The appearance of new strains of viruses predetermines both the improvement of existing and the search for new rapid diagnostic tests for infectious diseases. To improve the effectiveness of CEI for rapid diagnostics of viral diseases, we combined a precipitation reaction (precipitation of a certain antigen from a colloidal solution under the influence of serum specific antibodies with the formation of the antigen + antibody complex and sedimentation) with fluorescence using new fluorescein copolyesters. A generalized scheme of the elemental unit structure of fluorescein-containing copolyesters is shown in Fig. 1.

Polymeric products based on lipophilic 2-(octadecanoylamino) pentanedioic acid, hydrophilic polyoxyethylene diol with a molecular weight of 1000 or 1500 , dipropylene glycol and fluorescein were obtained according to the procedure and their characteristics are shown in Table 1.
The synthesized copolyesters exhibit amphiphilic properties and are capable of forming self-stabilized dispersed media in water [17]. Moreover, they contain a dye (fluorescein) capable of fluorescence at $\mathrm{pH} 7$ and higher $\mathrm{pH}$. Due to this, the new copolyesters are used as fluorogenic markers to obtain images from the biological objects environment [18].

After immunoelectrophoresis, the precipitation zones between the antigen (inactivated vaccine viruses) and serum antibodies were formed on the gel plates. The zones were formed in response to the introduced vaccine and characterize the reaction-response of the immune system of the rabbit organism (Fig. 2).

Precipitation zones and, respectively, the formation of antibodies on the $14^{\text {th }}$ day of research are clearly observed. At the same time, before the vaccination, the protein content of the antigen + antibody precipitation zones (both without and with the use of the fluorescein copolymer in the antigen composition) was in the range of 31.3-36.1\% (Fig. 3, Table 2).

On the $14^{\text {th }}$ day after vaccination, the antigenantibody complex content in the precipitation zone changed: it was by $15.1-23.6 \%(P<0.01-0.001)$ higher in CIE with complex between fluorescein copolymer and the antigen than in CIE without polymer. The established differences were maintained during the study of the content of complexes between antigen and antibody after 21 days. The difference between the use of a fluorescein copolymer in the complex with the antigen, compared to pure antigen, was smaller (5.8-8.7\%), but remained statistically significant $(P<0.05-0.01)$.

It should be noted that for some animals the antigen-antibody precipitation zones were detected before vaccination. Apparently, their presence was caused by passive immunity provided by immunized female rabbits. Thus, the presence of antibodies against hemorrhagic disease agents in the blood of young rabbits (up to 1 month) can indirectly charac-

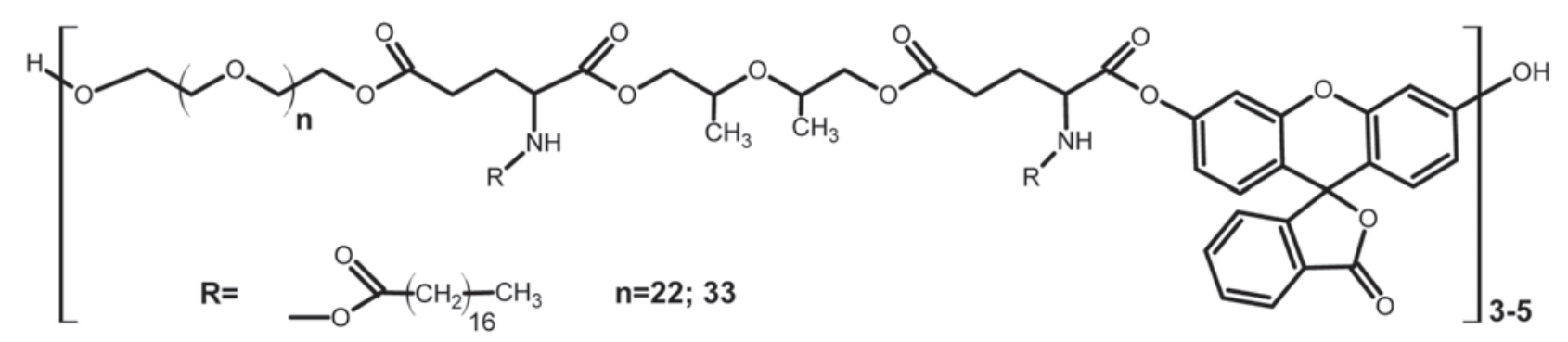

Fig. 1. Generalized scheme of the copolyester elemental unit structure 
Table 1. Characteristics of fluorescein copolyesters

\begin{tabular}{|c|c|c|}
\hline \multirow{2}{*}{$\begin{array}{l}\text { Characteristics of new } \\
\text { fluorescein copolyesters }\end{array}$} & \multicolumn{2}{|c|}{ Generalized structural formula } \\
\hline & $\begin{array}{l}\text { GluSt-PEG1000-DPG-F; } \\
\text { MF-37 }\end{array}$ & $\begin{array}{l}\text { GluSt-PEG1500-DPG-F; } \\
\text { MF-47 }\end{array}$ \\
\hline \multicolumn{3}{|l|}{ Monomers ratio in copolyester, mole parts: } \\
\hline Acid & 0.5 & 0.50 \\
\hline PEG & 0.27 & 0.30 \\
\hline DPG & 0.09 & 0.09 \\
\hline Fluorescein $(F)$ & 0.14 & 0.11 \\
\hline Fluorescein content in the polymer, \% & 5.87 & 2.40 \\
\hline $\mathrm{MM}, \mathrm{Da}$ & 6150 & 7750 \\
\hline CMC, \% & 0.0052 & 0.007 \\
\hline Hydrophylic-lipophylic balance (HLB) & 6.30 & 7.70 \\
\hline$\zeta$ - potential, $\mathrm{mV}$ & -25.60 & -22.30 \\
\hline
\end{tabular}

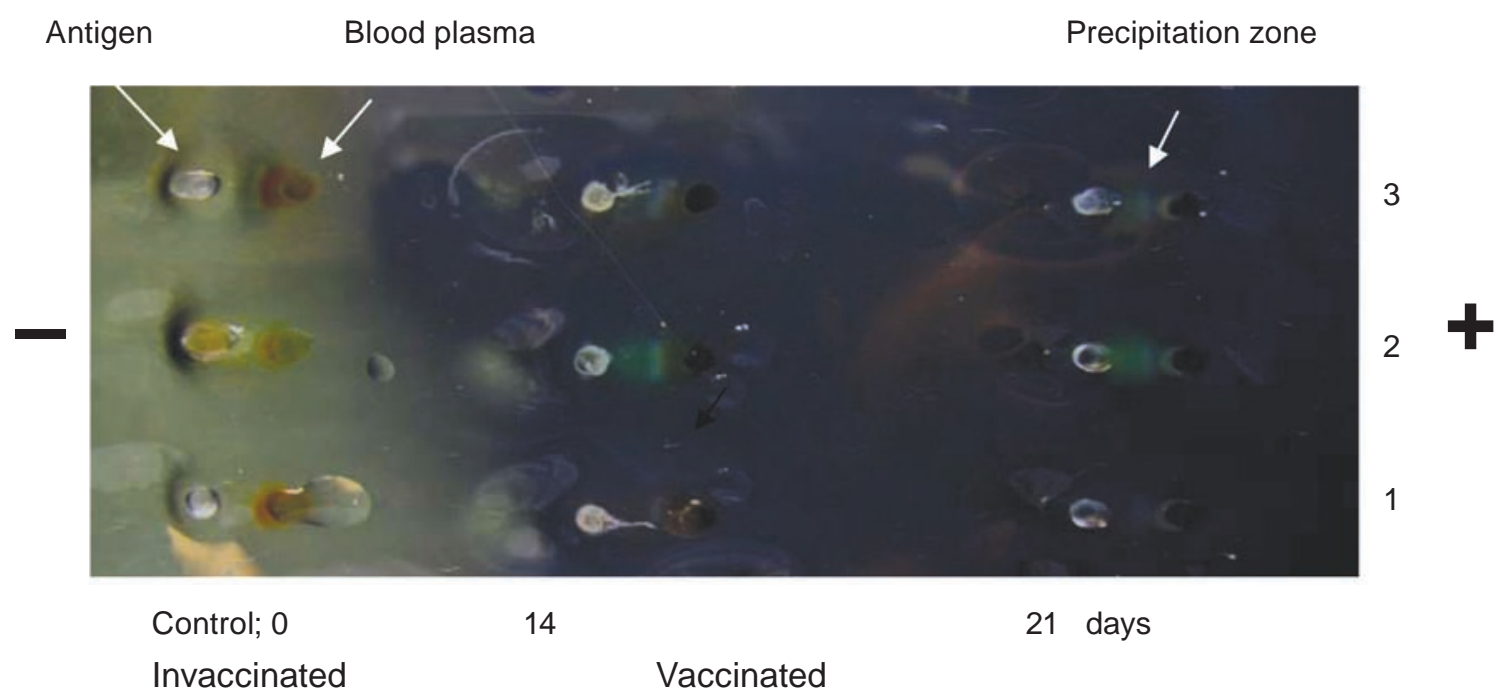

Fig. 2. Results of immunization of young rabbits with vaccine against hemorrhagic disease on the $14^{\text {th }}$ and $21^{\text {st }}$ days: sample 1 -antigen without fluorescein copolymer; sample 2 - antigen with modifications of fluorescein copolymer MF-37; sample 3 - antigen with modifications of fluorescein copolymer MF-47

terize the immunity state of female rabbits from which they are originated.

Repeated studies of the antigen-antibody complex content in the fluorescein copolymer complex confirm that fluorescein copolymer addition to the antigen makes the appearance of precipitation zones more intense (Figs. 4, 5).

Particularly, before vaccination, the concentration of the antigen-antibody complex in precipitation zones (without and with the use of the fluorescein copolymer in the antigen composition) was in the range of $31.3-36.2 \%$ (Table 3).
After 14 days of vaccination the highest protein content in the precipitation zone $(41.1 \pm 4.86 \%)$ was observed for the samples using the fluorescein copolymer MF-37; the lower value $(32.5 \pm 4.15 \%)$ was observed using the polymer MF-47 and the lowest one $(6.1-14.7 \%, P<0.05)$ was determined for the samples without polymers. The established relation between the samples with and without fluorescein copolymer was also preserved after 21 and 28 days of imminization $(9.2-16.7 \%, P<0.05)$ and $1.7-2.7 \%$, respectively. 


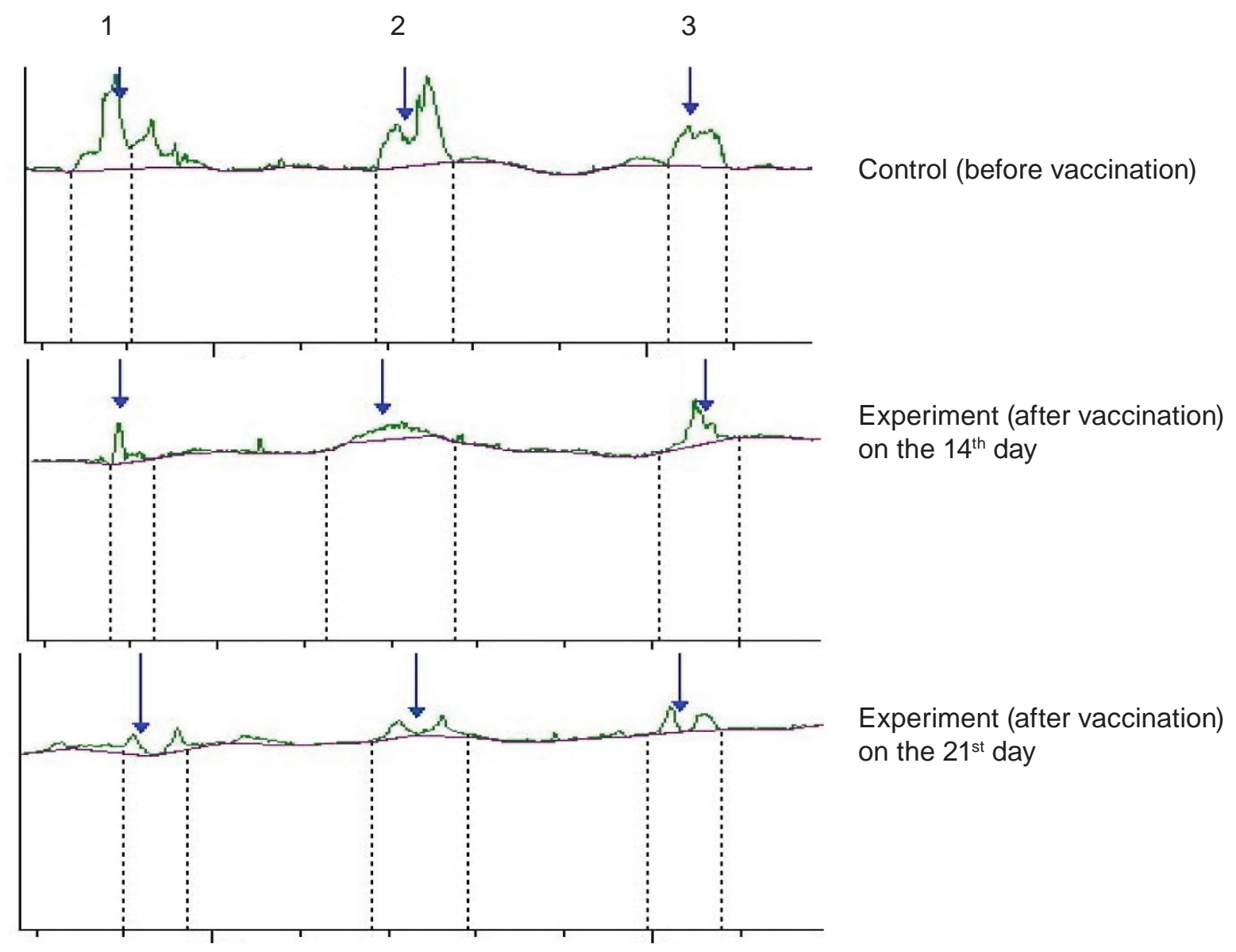

Fig. 3. Immunoelectrophoresis densitograms of precipitation reaction between antigen and antibody: 1 - antigen without fluorescein copolymer; 2 - antigen with modifications of fluorescein copolymer MF-37; 3 - antigen with modifications of fluorescein copolymer MF-47. The arrow indicates precipitation zone

Ta ble 2. The concentration of the antigen-antibody complex in the precipitation zones, $(M \pm m, n=6)$

\begin{tabular}{l|c|c|c}
\hline \multirow{2}{*}{$\begin{array}{c}\text { Experimental } \\
\text { conditions, days }\end{array}$} & \multicolumn{3}{|c}{ The ratio between the content of antigen-antibody complexes in the samples, \% } \\
\cline { 2 - 4 } & Control (without polymer) & Polymer MF-37 & Polymer MF-47 \\
\hline 0 (before vaccination) & $32.60 \pm 1.63$ & $36.10 \pm 2.38$ & $31.30 \pm 2.24$ \\
14 & $20.50 \pm 1.57$ & $44.10 \pm 1.89^{* * *}$ & $35.60 \pm 2.95^{* *}$ \\
21 & $28.50 \pm 1.30$ & $37.20 \pm 1.78^{* *}$ & $34.30 \pm 1.70^{*}$ \\
\hline
\end{tabular}

Note. Data were compared to the control. The difference is judged to be statistically significant when: $* P<0.05$; $* * P<0.01 ; * * * P<0.001$

Ta b le 3. The concentration of the antigen-antibody complex in the precipitation zones, $(M \pm m, n=3)$

\begin{tabular}{l|c|c|c}
\hline \multirow{2}{*}{$\begin{array}{c}\text { Experimental } \\
\text { conditions, days }\end{array}$} & \multicolumn{3}{|c}{ The ratio between the content of antigen-antibody complexes in the samples, \% } \\
\cline { 2 - 4 } & Control (without polymer) & Polymer MF-37 & Polymer MF-47 \\
\hline 0 (before vaccination) & $32.50 \pm 1.27$ & $36.20 \pm 2.38$ & $31.30 \pm 2.24$ \\
14 & $26.40 \pm 0.86$ & $41.10 \pm 4.86^{*}$ & $32.50 \pm 4.15$ \\
21 & $27.20 \pm 2.91$ & $43.90 \pm 4.45^{*}$ & $28.90 \pm 3.42$ \\
28 & $29.30 \pm 2.51$ & $38.60 \pm 1.69^{*}$ & $32.10 \pm 1.24$ \\
\hline
\end{tabular}

Note. Data were compared to the control. The difference is judged to be statistically significant when: ${ }^{*} P<0.05$ 


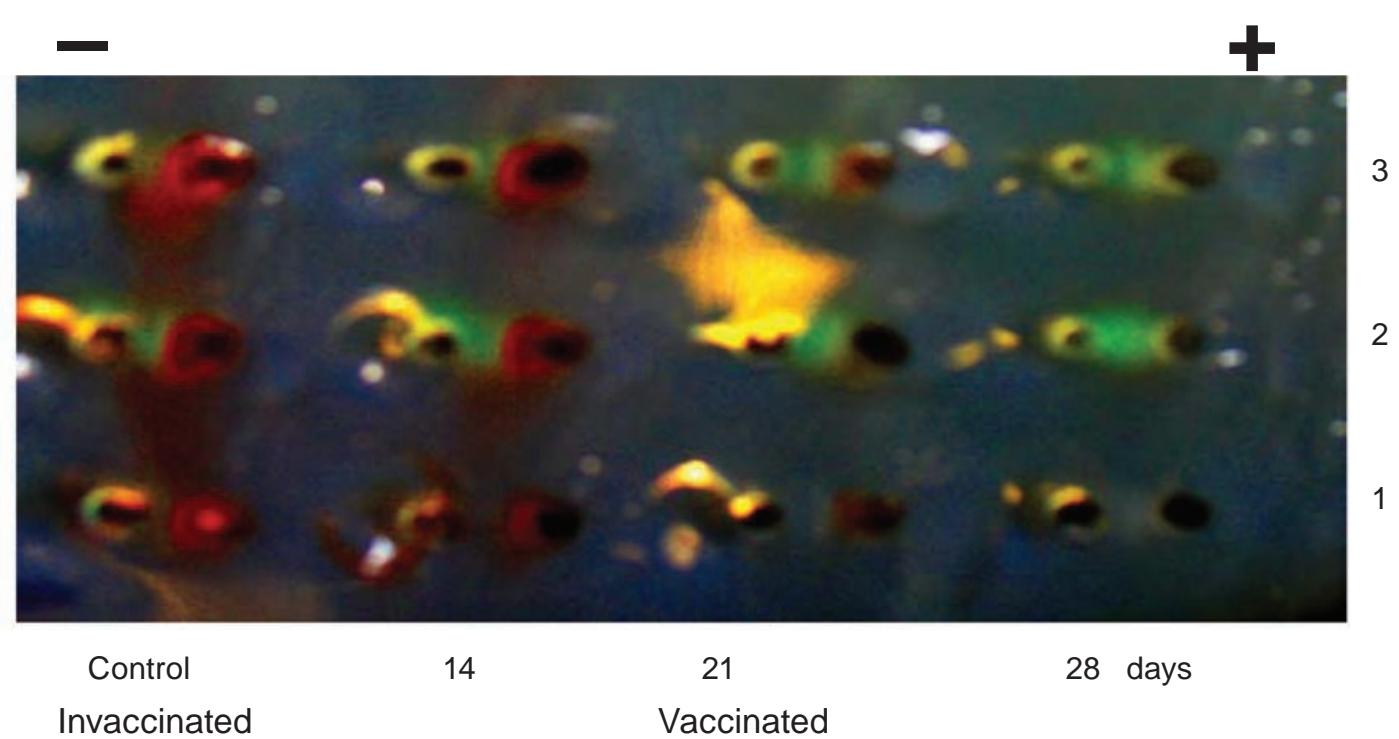

Fig. 4. Results of immunization of young rabbits with a vaccine against hemorrhagic disease using the fluorescein copolymer for 28 days: sample 1 - antigen without fluorescein copolymer; sample 2 - antigen with modifications of fluorescein copolymer MF-37; sample 3 - antigen with modifications of fluorescein copolymer MF-47

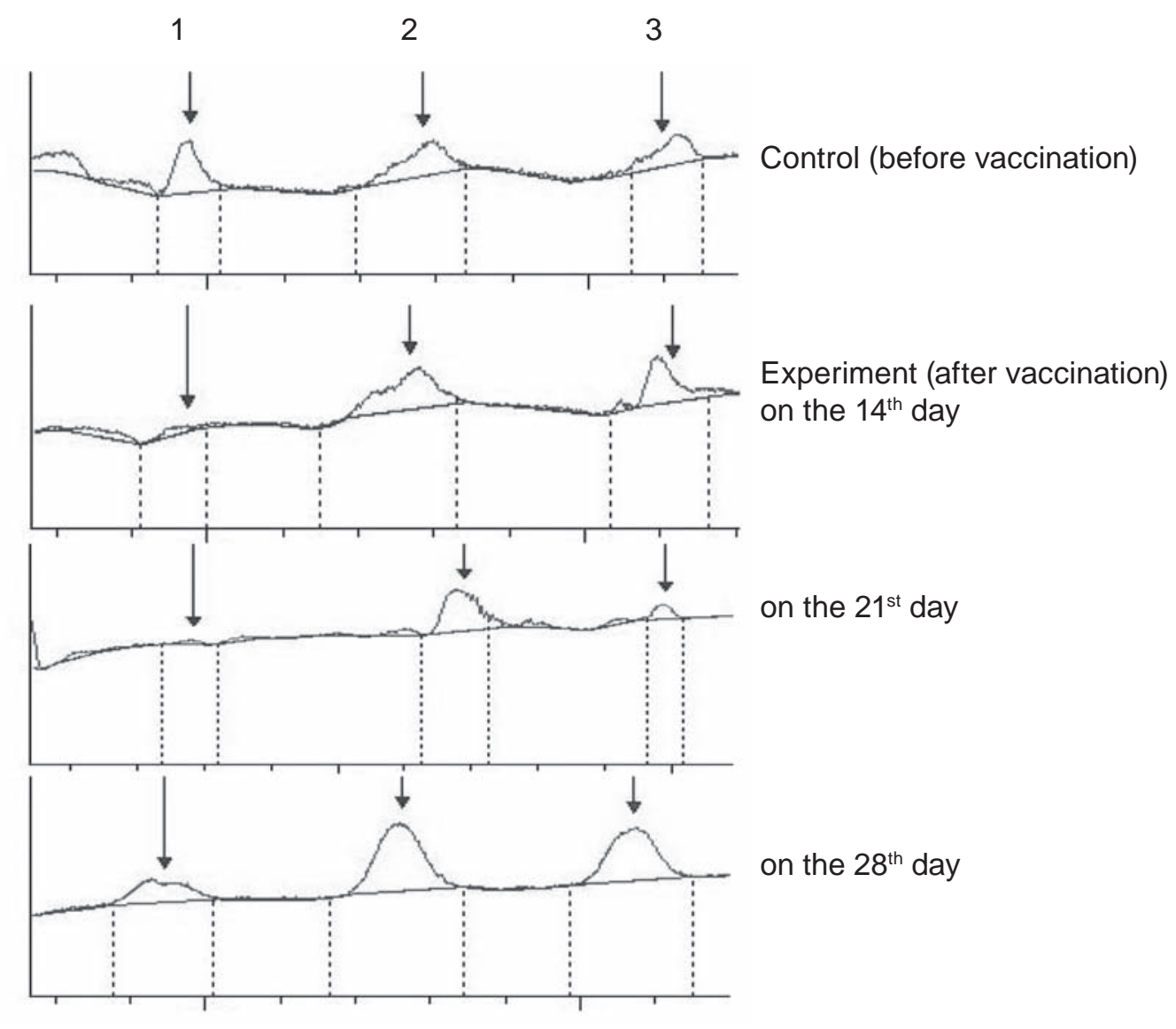

Fig. 5. Immunoelectrophoresis densitograms of precipitation reaction between the antigen and antibody: 1 - antigen without fluorescein copolymer; 2 - antigen with modifications of fluorescein copolymer MF-37; 3 - antigen with modifications of fluorescein copolymer MF-47. The arrow indicates precipitation zone 
Ta ble 4. The dynamics of complex formation between antigen (with fluorescein copolymer) and antibody after 28 days from the immunization of young rabbits against hemorrhagic disease, $(M \pm m)$

\begin{tabular}{l|c|c|c}
\hline \multirow{2}{*}{$\begin{array}{c}\text { Experimental } \\
\text { conditions, days }\end{array}$} & \multicolumn{3}{|c}{ The ratio between the content of antigen-antibody complexes in the samples, \% } \\
\cline { 2 - 4 } & $\begin{array}{c}\text { Control (without } \\
\text { polymer), } n=6\end{array}$ & Polymer MF-37, $n=3$ & Polymer MF-47, $n=3$ \\
\hline 0 (before vaccination) & $13.10 \pm 1.43$ & $11.90 \pm 1.28$ & $12.70 \pm 1.59$ \\
14 & $19.70 \pm 1.71^{*}$ & $18.60 \pm 0.78^{* *}$ & $21.20 \pm 1.68^{*}$ \\
21 & $26.20 \pm 1.76^{* * *}$ & $26.70 \pm 1.34^{* * *}$ & $28.20 \pm 2.56^{* *}$ \\
28 & $41.00 \pm 2.97^{* * *}$ & $42.80 \pm 1.42^{* * *}$ & $37.90 \pm 2.68^{* * *}$ \\
\hline
\end{tabular}

Note. Data were compared to the control. The difference is judged to be statistically significant when: $* P<0.05$; $* * P<0.01 ; * * * P<0.001$

The efficacy of using fluorescein copolymer to improve the specificity of the antigen-antibody binding reaction during CEI was confirmed by changes in the formation of antigen-antibody complexes for 28 days (Table 4).

Hence, the percentage content of antigen-antibody complexes increased from 11.9-13.1\% (before vaccination) to $25.2-30.9 \%(P<0.05-0.001)$ on $28^{\text {th }}$ day after vaccination. Moreover, in each period of study, the difference between the values of protein content in the precipitation zone without and with the use of the fluorescein copolymer was within the error of the arithmetic mean (0.3-4.9\%). The experimental results indicate the formation of antibodies in the animal body in response to the introduced pathogen and the suitability of the fluorescein copolymer for diagnostic studies. At the same time, a strong correlation $(\eta=0.983)$ between the increase of protein content in the precipitate zone and the day of study characterizes the advantage of the fluorescein copolymer MF-37 for diagnostic study. This copolymer enhances the antigen + antibody interaction for detection of specific antibodies (or pathogene(s) if specific antibodies are present) during the ascertainment of the strength of the immune response and infectious disease diagnostic by CEI.

In this manner, during diagnostic studies using CEI the fluorescein copolymer complex in the antigen composition intensifies the precipitation with serum (plasma) antibodies for rabbits immunized against hemorrhagic disease. The content of antigen-antibody complexes in the precipitation zone increases by $1.7-16.7 \%(P<0.05)$. During CIE the appearance of precipitation zones is the most intense when more hydrophobic (HLB = 6.3) copolymer MF-37 containing $5.87 \%$ of fluorescein is used in the antigen complex with antigen. The ability of fluorescein amphiphilic copolymer to enhance the antigenantibody interaction together with the fluorescence possibility to visualize the precipitation zone can be used to improve the efficiency of the CIE rapid diagnostics for detecting antibodies (or antigen if specific antibodies are present) during the ascertainment of the strength of the immune response and infectious diseases diagnosis in animals. CEI using the fluorescein-containing amphiphilic copolymer is rapid and easy to perform assay which provides visual control and result recording.

Conflict of interest. Authors have completed the Unified Conflicts of Interest form at http://ukrbiochemjournal.org/wp-content/uploads/2018/12/ coi_disclosure.pdf and declare no conflict of interest.

Funding. The work was conducted on budget costs of NAAS of Ukraine, project N 0116U001397, and Lviv Polytechnic National University, project N $0118 U 000262$. 


\section{ЗАСТОСУВАННЯ \\ ФЛУОРЕСЦЕНТНОГО \\ КОПОЛІМЕРУ ДЛЯ ПІДВИЩЕННЯ \\ ЕФЕКТИВНОСТІ ЗУСТРІЧНОГО \\ ІМУНОЕЛЕКТРОФОРЕЗУ ЗА \\ ДІАГНОСТИКИ ІНФЕКЦИЙНИХ ХВОРОБ ТВАРИН}

\author{
Д. Д. Остапів 1 , Н. В. Кузьміна 1 , М. Р. Козак', \\ Шань Ху르, В. В. Влізло \\ С. М. Варваренко ${ }^{4}$ В. Я. Самарик ${ }^{4}$, \\ Н. Г. Носова ${ }^{4}$ М. В. Яковів ${ }^{4}$
}
${ }^{1}$ Інститут біології тварин НААН, Львів, Україна;
${ }^{2}$ Сільськогосподарський університет м. Циндао, КНР;
${ }^{3}$ Державний науково-дослідний контрольний інститут ветеринарних препаратів та кормових добавок, Львів, Україна;
${ }^{4}$ Національний університет «Львівська політехніка», Україна;
巴e-mail: vasyl.vlizlo@scivp.lviv.ua

Метод зустрічного імуноелектрофорезу (ЗІЕФ) характеризується високою спефічністю, простотою і швидкістю проведення діагностичних досліджень без використання дорогого обладнання, витратних матеріалів та тривалого навчання персоналу. Попри високу інформативність (до 98-100\%) результати застосування в експресдіагностиці можуть бути сумнівними. Тому метою досліджень було підвищити ефективність ЗІЕФ шляхом посилення взаємодії антигену з антитілом за використання синтезованого амфіфільного флуоресцеїновмісного кополімеру. Встановлено, що комплекс кополімер флуоресцеїн-антиген посилював взаємодію з антитілами сироватки/ плазми крові імунізованих проти геморагічної хвороби кролів, що виявлялось у підвищенні вмісту протеїнів у зоні преципітації в разі проведення ЗІЕФ. Цей ефект був виразнішим за введення до складу комплексу з антигеном більш гідрофобного кополімеру, що містив 5,87\% флуоресцеїну. Здатність амфіфільного флуоресцентного кополімеру посилювати взаємодію антиген-антитіло та можливість візуалізувати флуоресцентні зони преципітації можуть підвищити ефективність ЗІЕФ як експрес-методу для виявлення антитіл за оцінки напруженості імунітету під час діагностики інфекційних хвороб.
К л ю чо в і с лов в: експрес-діагностика, зустрічний імуноелектрофорез, амфіфільний кополімер флуоресцеїну, геморагічна хвороба кролів.

\section{References}

1. Kornienko LE, Golovakha VI, Yarchuk BM, Golovko AM, Wild OV, Kornienko LM, Dombrovsky OB, Tirsin RV, Tirsina Yu.M. Parvovirus infections of dogs and fur animals. Bila Tserkva: Bila Tserkva National Agrarian University, 2001. 55 p. (In Ukrainian).

2. Queiroz da Silva LH, Moreira Wildeberg C, Moura Wlamir C, Silva Marlon V. Demonstration of viral antibodies by the counterimmunoelectrophoresis Test. In book Current Laboratory Techniques in Rabies Diagnosis, Research and Prevention. Academic Press, 2015. 384 p.

3. Silva LH, Bissoto CE, de Carvalho C, Cardoso TC, Pinheiro DM, Perri SH. Comparison between the counter immunoelectrophoresis test and mouse neutralization test for the detection of antibodies against rabies virus in dog sera. Mem Inst Oswaldo Cruz. 2002; 97(2): 259-261.

4. Ravinder PT, Parija SC. Countercurrent immunoelectrophoresis test for detection of hydatid antigen in the fluid from hydatid cysts: a preliminary report. Acta Trop. 1997; 66(3): 169-173.

5. Raj GD, Thangavelu A, Elankumaran S, KoteeswaranA. Rocket immunoelectrophoresis in the diagnosis of infectious bursal disease. Trop Anim Health Prod. 2000; 32(3): 173-178.

6. Imtiaz F, Akhtar M, Awai M, Muhammad F, Huma J. Standardization and Application of Modified Counter Immuno-Electrophoresis for the Detection of Antigenic Response against Haemonchus contortus in Rabbits. Pak J Life Soc Sci. 2011; 9(1): 13-16.

7. Manzoor S, Rahman SU, Khan IA. Identification, and Titration of Hydro Pericardium Syndrome Virus (HPSV) by using Modified Counter-Current Immuno-Electrophoresis (MCCIE). $J$ Antivir Antiretrovir. 2017; 9(2): 52-54.

8. Farid AH, Hussain I, Arju I. Detection of Aleutian mink disease virus DNA and antiviral antibodies in American mink (Neovison vison) 10 days postinoculation. J Vet Diagn Invest. 2015; 27(3): 287294.

9. Kucheryavenko RO. Detection of bovine coronavirus antigen. Vet Med. 2009; 92: 266-270. (In Ukrainian).

10. Chekh BO, Ferens MV, Ostapiv DD, Samaryk VY, Varvarenko SM, Vlizlo VV. Characteristics of novel polymer based on pseudo-polyamino acids GluLaDPG-PEG600: Binding of albumin, biocompatibility, biodistribution and potential crossing the blood-brain barrier in rats. Ukr Biochem J. 2017; 89(4): 13-21. 
11. Varvarenko SM, Ferens MV, Samaryk VYa, Nosova NG, Fihurka NV, Ostapiv DD, Voronov SA. Synthesis of copolyesters of fluorescein and 2-(dodecanamino) pentanedionic acid via steglich reaction. Vopr Khimii Khim Tekhnol. 2018; (2): 5-15.

12. Pat. 98749 UA, ICP(2006), C08G 77/46, C08G 63/66, C08G 63/12, C08G 63/685, C08G 63/668. A method of obtaining copolyesters of natural dibasic $\alpha$-amino acids and glycol polyethers / Dron IA, Taras RS, Voronov SA, Varvarenko SM, Nagornyak MI, Figurka NV, Nosova NG, Samaryk VYa, Voronov AS, Ferens MV, Tarnavchyk IT. Publ. 12.05.2015, Bul. N 9. (In Ukrainian).

13. Yakoviv MV, Nosova NG, Samaryk VY, Pasetto P, Varvarenko SM. Study of physical interactions of fluorescein-containing amphiphilic copolyesters with albumin in aqueous dispersions. Appl Nanosci. 2020; 10(8): 2655-2663.

14. Tarnavchyk IT, Nosova NG, Panchenko AV, Maksymiv AB, Varvarenko SM. Sorption of albumin on the surface of the dispersed phase copolyestereters. Bull Nat Univ Lviv Polytechnic. Ser. Chem Technol Subst Appl. 2015; (812): 465-470. (In Ukrainian).

15. Kornienko LE, Glavatsky VP, Yarchuk BM, Kornienko LM, Mandigra MS, Dombrovsky OB, Tirsin RV. Viral haemorrhagic disease of rabbits. Bila Tserkva: Bila Tserkva National Agrarian University, 2001. 60 p. (In Ukrainian).

16. Yakoviv M, Fihurka N, Nosova N, Samaryk V, Vasylyshyn T, Hermanovych S, Voronov S, Varvarenko S. Researches in amphiphilic properties of copolyesters with chromophore groups. Chem Chem Technol. 2018; 12(3): 318-325.

17. Varvarenko SM, Samaryk VYa., Vlizlo VV, Ostapiv DD, Nosova NG, Tarnavchyk IT, Figurka NV, Ferens MV, Nagornyak MI, Taras RS, Yaremchuk IM, Voronov SA, Voronov AS. Fluorescein-containing theranostics based on the pseudo-poly(amino acid)s for monitoring of drug delivery and release. Polymer J. 2015; 37(2): 193-199. (In Ukrainian). 